\title{
A Study of Genetic Transformation in Gloeocapsa alpicola
}

\author{
By C. IMELDA DEVILLY* AND J. A. HOUGHTON \\ Department of Microbiology, University College, Galway, Ireland
}

(Received I March 1976; revised 6 August 1976)

INTRODUCTION

The first report of genetic transformation in blue-green algae was that of Shestakov \& Khyen (1970) who demonstrated the process in Anacystis nidulans. Transformation was effected by chemically-extracted DNA from drug-resistant mutants, and resembled bacterial transformation in that it was sensitive to DNAase. Transformation was later confirmed in this species by Herdman \& Carr (I97I), who also described a novel system of transformation mediated by an extracellular DNA/RNA complex. Herdman (1973a,b) presented evidence of an associated phenomenon of mutation in transformation of $A$. nidulans. To date, most reports of genetic transformation in blue-green algae have referred to $A$. nidulans, although it has also been demonstrated in Aphanocapsa (Astier \& Espardellier, 1976). This communication reports the study of a transformation system in Gloeocapsa alpicola, and describes attempts to transfer drug-resistance markers intergenerically between Anacystis and Gloeocapsa.

\section{METHODS}

Organisms and culture conditions. Axenic cultures of Gloeocapsa alpicola (Lyngbye) Bornet and Anacystis nidulans (Richt.) Drouet were obtained from the Culture Collection of Algae and Protozoa, Cambridge (collection numbers I430/I and I405/I respectively). The medium of Hughes, Gorham \& Zehnder (1958), as modified by Allen (I968), was used routinely for the culture of $A$. nidulans. For the growth of $G$. alpicola, the medium was supplemented with ethylenediaminetetraacetic acid (EDTA; o.o I $\mathrm{g}^{-1}$ ) to control the production of a slime layer/capsule around the cells and thus minimize cell clumping. Cultures were incubated at $34{ }^{\circ} \mathrm{C}, 50 \pm 5 \%$ relative humidity and a light intensity of 2500 lux from cool white fluorescent tubes. Adequate aeration was achieved by mounting the culture flasks on a rotary shaker operating at $\mathrm{I} 20 \mathrm{rev} . \mathrm{min}^{-1}$.

$D N A$ isolation. The algal cells were lysed by a method devised by Herdman (personal communication). Harvested cells ( 2 to $3 \mathrm{~g}$ wet wt) were suspended in $20 \mathrm{ml} 400 \mathrm{~mm}-\mathrm{NaCl}$ plus I00 mm-EDTA, $\mathrm{pH} 8 \cdot 0$. Lysozyme $\left(\mathrm{I} \mathrm{mg} \mathrm{ml}^{-1}\right)$ was added and the mixture was incubated, with stirring at $37{ }^{\circ} \mathrm{C}$ for $60 \mathrm{~min}$. Sodium aminosalicylate to a final concentration of $4 \%(\mathrm{w} / \mathrm{v})$ and sodium lauryl sulphate to a final concentation of $2 \%(\mathrm{w} / \mathrm{v})$ were added and the mixture was immersed in a $60{ }^{\circ} \mathrm{C}$ water bath for Io min. Marmur's (I96I) method was used for the isolation and purification of the DNA with slight modification: three to six deproteinizations were carried out consecutively without intermittent precipitation with ethanol, this step only being used after the series of deproteinizations. RNAase treatment was omitted. DNA preparations were analysed colorimetrically using a Pye Unicam SP500 ultraviolet or visible spectrophotometer. Yields of $\mathrm{I} \cdot 5 \mathrm{mg}$ DNA ( $\mathrm{g}$ wet cells) ${ }^{-1}$ were obtained

\footnotetext{
* Present address: Regional Technical College, Galway, Ireland.
} 
using these cell lysis and DNA extraction procedures. The samples contained no contaminating protein as estimated colorimetrically using the method of Layne (1957).

Transformation: method I. Recipient $A$. nidulans or G. alpicola cells were grown in liquid minimal medium for $76 \mathrm{~h}$, harvested and resuspended in minimal medium, to a concentration of $\mathrm{I} \times \mathrm{IO}^{8}$ cells $\mathrm{ml}^{-1}$. Donor DNA was added to the recipient cells $(5 \mathrm{ml})$ and incubated at $32{ }^{\circ} \mathrm{C}$ for 17 to $28 \mathrm{~h}$. Controls included samples with no DNA added, and samples containing recipient DNA, to eliminate the possibility of a mutagenic effect of DNA. After various time intervals, samples $(0.1 \mathrm{ml})$ were plated on to antibiotic-supplemented agar plates (containing streptomycin, $25 \mu \mathrm{g} \mathrm{ml}^{-1}$, or rifampicin, I00 $\mu \mathrm{g} \mathrm{ml}^{-1}$ ) and the frequency of transformants was scored against total viable counts on minimal medium. In some experiments DNAase $\left(50 \mu \mathrm{g} \mathrm{ml}^{-1}\right)$ plus $\mathrm{MgCl}_{2}\left(\mathrm{I} \mathrm{mg} \mathrm{ml}^{-1}\right)$ was added to the reaction mixture for 30 min to terminate the action of any remaining DNA. The effects of DNAase and RNAase on transforming activity were investigated in some cases by incubating the reaction mixtures with DNAase $\left(50 \mu \mathrm{g} \mathrm{ml}^{-1}\right)$ plus $\mathrm{MgCl}_{2}$ (I mg ml$\left.{ }^{-1}\right)$, RNAase $\left(50 \mu \mathrm{g} \mathrm{ml}^{-1}\right)$, or both DNAase and RNAase. RNAase was dissolved in $0.15 \mathrm{M}-\mathrm{NaCl}$ and pretreated at $80{ }^{\circ} \mathrm{C}$ for Io min to destroy any contaminating DNAase. The sterility of the donor DNA was tested by plating samples on to minimal medium. The rates of appearance of spontaneous mutations of recipients to antibiotic resistance were estimated by plating samples of the wild-type strain on to medium supplemented with the appropriate antibiotics.

Transformation: method 2. A modification of the method of Cohen, Chang \& Hsu (1972) was used. Recipient cells were grown to a density of $\mathrm{I} \cdot 0 \times 10^{8}$ cells $\mathrm{ml}^{-1}$, chilled quickly, sedimented and washed once in $0.5 \mathrm{vol}$. $10 \mathrm{mM}-\mathrm{NaCl}$, centrifuged again and resuspended in 0.5 original vol. of chilled $30 \mathrm{~mm}-\mathrm{CaCl}_{2}$ The suspension was held at $0{ }^{\circ} \mathrm{C}$ for $20 \mathrm{~min}$, then centrifuged and resuspended in 0.1 original vol. $30 \mathrm{mM}-\mathrm{CaCl}_{2}$ solution. Donor DNA was chilled and supplemented with $100 \mathrm{mM}-\mathrm{CaCl}_{2}$ to a final concentration of $30 \mathrm{~mm}$. Reaction mixtures were prepared as follows. $\mathrm{CaCl}_{2}$-treated recipient cells (I $\mathrm{ml}$ ) plus $\mathrm{CaCl}_{2}$-treated donor DNA $(0.1$ to $0.5 \mathrm{ml})$ were incubated in a $40^{\circ} \mathrm{C}$ water bath for $15 \mathrm{~min}$ to allow uptake of DNA. Incubation was continued at $32{ }^{\circ} \mathrm{C}$ for $18 \mathrm{~h}$, after which the suspension was diluted Io-fold into minimal medium and allowed to grow for 2 to 3 days before selection of transformants on antibiotic-supplemented agar.

\section{RESULTS}

Transfer of antibiotic-resistance markers from mutant strains of G. alpicola to the wildtype strain was unsuccessful using transformation method I. Modification of the technique including variations in the age of the recipient culture, DNA concentration, duration of incubation in the presence of DNA and treatment with DNAase to terminate the reaction failed to produce successful transfer. To determine whether this failure was due to some intrinsic property of the donor DNA which impaired its transforming ability or was indicative of non-transformability of the recipient $G$. alpicola cells by chemically-extracted DNA, experiments were carried out to examine the transfer of antibiotic resistance from mutant strains of $G$. alpicola to wild-type $A$. nidulans recipients. Results obtained from this intergeneric transformation are presented in Table I. Streptomycin-resistant $A$. nidulans transformants were isolated at a frequency that depended on the concentration of donor DNA and the incubation period. The maximum frequency was $2.6 \times 10^{-3}$, that is $6 \times 10^{3}$-fold higher than the frequency of spontaneous appearance of streptomycin-resistant mutants $\left(4.4 \times 10^{-7}\right)$. Microscopic examination indicated that the transformants exhibited the morphological features characteristic of Anacystis species. The transformants were stable on repeated 
Table I. Intergeneric transfer of streptomycin resistance from

\section{G. alpicola to $A$. nidulans}

\begin{tabular}{|c|c|c|c|c|c|c|}
\hline Donor DNA & Recipient & $\begin{array}{l}\text { No. of } \\
\text { cells } \mathrm{ml}^{-1}\end{array}$ & $\begin{array}{l}\text { DNA concn } \\
\left(\mu \mathrm{g} \mathrm{ml}^{-1}\right)\end{array}$ & $\begin{array}{l}\text { Incubation } \\
\text { period }(\mathrm{h})\end{array}$ & Enzyme & $\begin{array}{l}\text { Transfer fre- } \\
\text { quency (per } \\
\text { recipient cell) }\end{array}$ \\
\hline $\operatorname{Str}^{\mathrm{r}} G$. & Wild-type $A$. & $1 \cdot 2 \times 10^{6}$ & 20 & I7 & - & $3.3 \times 10^{-5}$ \\
\hline $\operatorname{Str}^{r} G$ & Wild-type $A$. & $1 \cdot 2 \times 10^{6}$ & 20 & 19 & - & $2.5 \times 10^{-6}$ \\
\hline $\operatorname{Str}^{r} G$ & Wild-type $A$. & $\mathrm{I} \cdot 2 \times 10^{6}$ & 40 & 23 & - & $3.6 \times 10^{-6}$ \\
\hline $\operatorname{Str}^{r} G$ & Wild-type $A$. & $1.2 \times 10^{6}$ & 20 & 28 & - & $2.5 \times 10^{-4}$ \\
\hline $\operatorname{Str}^{r} G$. & Wild-type $A$. & $1 \cdot 2 \times 10^{6}$ & 40 & 28 & - & $1.6 \times 10^{-6}$ \\
\hline - & Wild-type $A$. & $1 \cdot 2 \times 10^{6}$ & - & 28 & - & $O\left(<5 \times 10^{-7}\right)$ \\
\hline $\operatorname{Str}^{r} G$ & Wild-type $A$. & $6.6 \times 10^{7}$ & 20 & 20 & - & $2.6 \times 10^{-3}$ \\
\hline $\operatorname{Str}^{r} G$ & Wild-type $A$. & $6.6 \times 10^{7}$ & 20 & 20 & DNAase & $4 \cdot 1 \times 10^{-4}$ \\
\hline $\mathrm{Str}^{2} G$ & Wild-type $A$. & $6.6 \times 10^{7}$ & 20 & 20 & RNAase & $I \cdot I \times 10^{-3}$ \\
\hline $\operatorname{Str}^{r} G$ & Wild-type $A$. & $6.6 \times 10^{7}$ & 20 & 20 & $\begin{array}{l}\text { DNAase } \\
+ \text { RNAase }\end{array}$ & $6.4 \times 10^{-4}$ \\
\hline $\operatorname{Str}^{r} G$ & - & - & 20 & 20 & 一 & 0 \\
\hline - & Wild-type $A$. & $6.6 \times 10^{7}$ & - & 20 & - & $4.4 \times 10^{-7}$ \\
\hline
\end{tabular}

G., Gloeocapsa alpicola; A., Anacystis nidulans.

Table 2. Intergeneric and intraspecific transformation of G. alpicola

\begin{tabular}{|c|c|c|c|c|c|}
\hline Donor DNA & Recipient & No. of cells ml-1 & $\begin{array}{l}\text { DNA concn } \\
\left(\mu \mathrm{g} \mathrm{ml}^{-1}\right)\end{array}$ & $\begin{array}{l}\text { Incubation } \\
\text { period }(\mathrm{h})\end{array}$ & $\begin{array}{l}\text { Transfer frequency } \\
\text { (per recipient cell) }\end{array}$ \\
\hline $\operatorname{Str}^{r} G$. & $\begin{array}{l}\text { Wild-type } G \text {. } \\
\text { Wild-type } G \text {. }\end{array}$ & $\begin{array}{l}6.0 \times 10^{7} \\
6.0 \times 10^{7}\end{array}$ & 20 & $\begin{array}{l}18 \\
18\end{array}$ & $0\left(\begin{array}{c}3.1 \times 10^{-3} \\
0\left(<6 \times 10^{-7}\right)\end{array}\right.$ \\
\hline$\overline{\operatorname{Str}^{r} G .}$ & Wild-type $A$. & $6.0 \times 10^{7}$ & 20 & 20 & $2.6 \times 10^{-3}$ \\
\hline - & Wild-type $A$. & $6.6 \times 10^{7}$ & - & 20 & $4.4 \times 10^{-7}$ \\
\hline $\operatorname{Rif}^{\mathrm{r}} A$. & Wild-type $G$. & $1 \cdot 0 \times 10^{8}$ & 20 & 18 & $7.5 \times 10^{-7}$ \\
\hline - & Wild-type $G$. & $1.0 \times 10^{8}$ & - & 18 & $O\left(<\mathrm{I} \times 10^{-8}\right)$ \\
\hline
\end{tabular}

G., Gloeocapsa alpicola; A., Anacystis nidulans.

transfer of individual colonies on to streptomycin-supplemented media, indicating that the newly-acquired resistance was a heritable property. DNAase and RNAase, both singly and together, reduced the frequency of transformation significantly. These experiments confirmed the transforming ability of chemically-extracted G. alpicola DNA.

Method 2 was used in an attempt to sensitize $G$. alpicola recipient cells to transformation by calcium chloride treatment. The results are summarized in Table 2. Transfer of the streptomycin-resistance marker from $\operatorname{Str}^{\mathrm{r}}$ G. alpicola to the wild-type parental strain occurred at a frequency of $3 . \mathrm{I} \times 10^{-3}$, i.e. intraspecific transformation. Intergeneric transformation of rifampicin resistance from $\operatorname{Rif}^{r} A$. nidulans to wild-type $G$. alpicola also occurred although the frequency of transfer was relatively low $\left(7.5 \times 10^{-7}\right)$. However, this was at least 75 -fold higher than the spontaneous mutation rate of rifampicin resistance in G. alpicola.

\section{DISCUSSION}

DNA for transformation studies was isolated very successfully using lysozyme, sodium lauryl sulphate and sodium aminosalicylate for cell lysis followed by the purification procedure of Marmur (196I). The additive effects of sodium lauryl sulphate and sodium aminosalicylate enhanced the lytic action of lysozyme. Crespi, Mandeville \& Katz (1962) showed that lysis by lysozyme alone was not feasible for many blue-green algal species. The inclusion of other agents may, therefore, be significant in effecting greater lysis of 
G. alpicola, particularly since this organism tends to be mucilaginous. The use of successive deproteinizations without intermittent ethanol precipitation resulted in greater final yields of DNA.

Most previous reports on transformation have concerned either A. nidulans or Aphanocapsa (Astier \& Espardellier, 1976) and have involved intraspecific transfer of drug resistance and auxotrophic requirements. The present study presents preliminary evidence of a transformation system in G. alpicola and the first demonstration of intergeneric transfer of antibiotic-resistance markers from $A$. nidulans to $G$. alpicola and vice versa. Transfer of streptomycin resistance from $G$. alpicola to $A$. nidulans was obtained at a maximum frequency of $2.6 \times 10^{-3}$ per recipient cell. Addition of DNAase and RNAase, both singly and together, to the incubation mixture showed that treatment with DNAase reduced the transforming efficiency by $84 \%$ whereas treatment with RNAase reduced it by $57.7 \%$. This suggests that both DNA and RNA are necessary for transformation but that DNA is the major contributor. This is in agreement with the findings of Herdman \& Carr (I97I) and Herdman (1973 $a, b$ ) for transformation in $A$. nidulans by an extracellular DNA/RNA complex but does not agree with their studies on transformation mediated by chemically-extracted DNA which was found to be sensitive to DNAase alone. The demonstration of intergeneric transformation has considerable interest, for example, markers for nitrogen-fixing ability may be transferable between blue-green algal species or genera.

\section{REFERENCES}

Allen, M. M. (1968). Simple conditions for growth of unicellular blue-green algae on plates. Journal of Phycology 4, I-4.

Astier, C. \& Espardellier, F. (1976). Mise en évidence d'un système de transfert genétique chez une cyanophycée du genre Aphanocapsa. Comptes rendus hebdomadaire des séances de l'Académie des sciences, série $D$ 282, 795-797.

Cohen, S. N., Chang, A. C. Y. \& Nsu, L. (1972). Non-chromosomal antibiotic resistance in bacteria. Genetic transformation of Escherichia coli by R-factor DNA. Proceedings of the National Academy of Sciences of the United States of America, 69, 2I IO-2II4.

Crespi, H. L., Mandeville, S. E. \& Katz, J. J. (1962). The action of lysozyme on several blue-green algae. Biochemical and Biophysical Research Communications 9, 569-573.

Herdman, M. (1973a). Transformation in the blue-green alga, Anacystis nidulans, and an associated phenomenon of mutation. Proceedings of the First European Meeting on Bacterial Transfer, pp. 369-386. Edited by Louis Archer. New York and London: Academic Press.

Herdman, M. (1973 b). Mutations arising during transformation in the blue-green alga, Anacystis nidulans. Molecular and General Genetics 120, 369-378.

Herdman, N. \& CARr, N. G. (197I). Recombination in Anacystis nidulans mediated by an extracellular DNA/RNA complex. Journal of General Microbiology 68, xiv.

Hughes, E. D., Gorham, P. R. \& ZeHNDer, A. (1958). Toxicity of a unialgal culture of Microcystis aeruginosa. Canadian Journal of Microbiology 4, 225-236.

LAYNe, E. (I957). Spectrophotometric and turbidimetric methods for measuring proteins. Methods in Enzymology 2, 447-454.

Marmur, J. (196r). A procedure for the isolation of deoxyribonucleic acid from microorganisms. Journal of Molecular Biology 3, 208-218.

Shestakov, S. V. \& KHYEN, N. T. (1970). Evidence for genetic transformation in blue-green alga, Anacystis nidulans. Molecular and General Genetics ro7, 372-375. 